Vol.45, n. 4 : pp. 499-513, December 2002

ISSN 1516-8913 Printed in Brazil

\section{BRAZILIAN ARCHIVES OF BIOLOGY AND TECHNOLOGY}

AN INTERNATIONAL JOURNAL

\title{
Seasonal Fluctuation of Some Limnological Variables on a Floodplain Lake (Patos lagoon) of the Upper Paraná River, Mato Grosso do Sul State, Brazil
}

\author{
Luzia Cleide Rodrigues*, Sueli Train, Maria do Carmo Roberto and Thomaz Aurélio \\ Pagioro \\ Universidade Estadual de Maringá; Núcleo de Pesquisas em Limnologia Ictiologia e Aqüicultura; Av. Colombo, \\ 5790; Bl. H-90; 87020-900; luziar@nupelia.uem.br; Maringá - Paraná - Brasil
}

\begin{abstract}
Temporal variations of some limnological variables in limnetic and littoral regions of Patos lagoon, a "várzea" lake on the floodplain of the Upper Paraná River $\left(22^{\circ} 43^{\prime} 12^{\prime \prime} \mathrm{S}\right.$ e 53 $\left.13^{\prime} 37^{\prime \prime} \mathrm{W}\right)$, were studied in relation to hydrological and climatological factors. Measurements of water temperature, euphotic zone, suspended material, electrical conductivity, total alkalinity, $\mathrm{pH}$, dissolved oxygen, carbon dioxide, total nitrogen, total Kjeldahl nitrogen, total phosphorus, dissolved phosphorus, reactive soluble phosphorus and chlorophyll a were taken monthly between March 1993 and February 1994. Results lend evidence to the importance of the hydrological regime on the dynamic of limnological variables in floodplain lakes. A dilution of nutrients in the lagoon, especially phosphates, occurred during floods. This was followed by fertilization of the environment by nutrients from the inundated marginal regions. During low connectivity periods, autochthonous, events such as ressuspension of sediment, brought on by wind and rain, governed limnological events in the lagoon.
\end{abstract}

Key words: Limnological variables, flood pulse, floodplain, Paraná River, connectivity, nutrients

\section{INTRODUCTION}

Wetlands are ecosystems subjected to periodic flooding and, depending on the intensity and duration of the flood, extensive transition zones between terrestrial and aquatic ecosystems can be formed where ecological conditions are constantly changing (Junk et al., 1989; Neiff, 1990). As a consequence, these environments are really a mosaic of aquatic biotopes with particular dynamic physical and chemical conditions. These conditions are also affected by the size, position and connectivity of these water bodies and the river (Junk, 1980; Junk et al., 1989).

Periodic flooding promotes an intensive exchange of nutrients between river and floodplain, consisting of an important forcing function for the dynamics of these complex ecosystems (Thomaz, 1991; Agostinho et al., 1995; Thomaz et al., 1997). Floodplain lakes are fundamental for the maintenance of floodplain biodiversity. These small lakes favour the development of aquatic macrophytes in the littoral zone during low water periods, contributing a great variety of niches for aquatic organisms (Zalocar de Domitrovic et al., 1998; Rodrigues, 1998) and breeding grounds for

* Author for correspondence 
many species of fish (Agostinho and Zalewski, 1996; Agostinho et al., 2000).

Several studies on floodplains have been undertaken; nevertheless, due to the diversity of these environments these researches are still scarce. Various investigations were carried out in Patos lagoon, concentrating on the effects of water level variations on different biological communities, such as phytoplankton (Train and Rodrigues, 1997; Rodrigues, L. C. 1998), periphyton (Rodrigues, L. 1998), zooplankton (Lansac-Tôha, et al., 1992; 1997; Serafim, 1997; Garcia et al., 1998) and zoobenthos (Takeda et al., 1997; Higuti, 1998). Studies focusing on the abiotic variables in other environments on the same floodplain were also undertaken by Thomaz et al. (1992; 1997), Pagioro et al. (1994; 1997), Pagioro and Thomaz (1999), among others.

The aim of this study was verifying the influence of the hydrological regime on limnological variables. We present data about seasonal fluctuations of some limnological variables under different hydrological and climatological conditions that Patos lagoon is subjected to, given its location on the floodplain of the Upper Paraná River.

\section{STUDY AREA}

Patos lagoon $\left(22^{\circ} 43^{\prime} 12^{\prime \prime} \mathrm{S}\right.$ and $\left.53^{\circ} 17^{\prime} 37^{\prime \prime} \mathrm{W}\right)$ is situated in Taquaruçú, Mato Grosso do Sul State, Brazil (Fig. 1). It is located on the left bank of the Ivinhema River, permanently connected by a channel. It is a small lake $\left(1.14 \mathrm{~km}^{2}\right)$ with maximum depth between 2.8 and $4.8 \mathrm{~m}$ (Souza Filho and Stevaux, 1997). Predominant macrophyte stands are Polygonum spp. and Eichhornia azurea Kunth and marginal vegetation is composed of shrubs and grasses. The Ivinhema River, one of the main tributaries of the Paraná River, has a width/depth ratio of 22:1 and current velocity is in the range of $0.85 \mathrm{~m} / \mathrm{s}$ (Souza Filho and Stevaux, 1997). The lower stretch of Ivinhema River flows through an area of the Upper Paraná River floodplain which still presents original environmental conditions (Agostinho and Zalewski, 1996).

\section{MATERIALS AND METHODS}

From March 1993 to February 1994, samples were taken between 9:00 and 13:00 in the limnetic region of the lagoon (P1), at sub surface and near the bottom; and in the littoral region (P2), near the macrophyte stands at sub surface. Water transparency was measured with a $30 \mathrm{~cm}$ Secchi disk. Water temperature was measured with a thermistor at $20 \mathrm{~cm}$ intervals. Water samples were collected with a Van Dorn sampler and held in polyethylene bottles for further laboratory analysis. The Euphotic zone was estimated according to Cole (1975); $\mathrm{pH}$ and conductivity were measured with portable digital potenciometers; dissolved oxygen was measured by the Winkler method modified by Golterman et al. (1978) and total alkalinity according to Mackereth et al. (1978).

Suspended material in the water column was determined by gravimetry technique (Wetzel and Likens, 1991) and the rates were calculated based on total suspended material values. Concentrations of total phosphorus (TP), reactive soluble phosphorus (SRP), total Kjeldahl nitrogen (TKN), soluble reactive silica, free carbon dioxide and bicarbonate were determined according to Mackereth et al. (1978). Total nitrogen was obtained by adding nitrite and nitrate to TKN. Particulate phosphate was obtained subtracting the total dissolved forms from total phosphate. Phytoplankton biomass estimated by chlorophyll $a$ concentrations was determined according to Golterman et al. (1978). Water level, Ivinhema River flow and precipitation were measured daily in Porto Sumeca (Mato Grosso do Sul). Values were furnished by the Departamento Nacional de Águas and Energia Elétrica (DNAEE).

For the numerical analyses, the mean water level values of the fourteen days preceding sampling were used because there was a temporal lag phase in the effect of fluctuating water levels in the different environments of the floodplain according to the connectivity between them (Thomaz et al., 1997).

In relation to water flow values, mean values of the two days preceding sampling were used because they were measured approximately $60 \mathrm{~km}$ upstream from the sampling area. For precipitation, values corresponding to the total precipitation of the two days preceding sampling were taken. 
In order to describe the study area limnologically, a Principal Component Analysis (PCA) was used. We included climatological and hydrological data, as well as physical and chemical water variables. Important factors showed a structure coefficient greater than 0.6. All variables except $\mathrm{pH}$ were previously $\log$ transformed. NtSys computer program was used to apply the PCA and STATISTICA (Statsoft Inc., 1996) to calculate Pearson correlations.

\section{RESULTS AND DISCUSSION}

Air temperature varied between $14^{\circ} \mathrm{C}$ (May and August) and $29.5^{\circ} \mathrm{C}$ (March), although high temperatures were also registered from September 1993 to February 1994 (Fig. 2).
The highest daily values of pluviometric precipitation during the study period occurred during March, May and October. No rain was registered during August. Higher precipitation values, however, were observed the day after sampling during November and December. This did not affect the data pattern.

In relation to water level values of the Ivinhema River (Fig. 3), it was seen that there were some months with levels higher than 2 meters (March, April, May, June 1993 and February 1994) and others with levels lower than 2 meters (July to December 1993). Water flow values varied between $793 \mathrm{~m}^{3} \cdot \mathrm{s}^{-1}$ (December 1993) and 190 $\mathrm{m}^{3} \cdot \mathrm{s}^{-1}$ (October and November 1993).

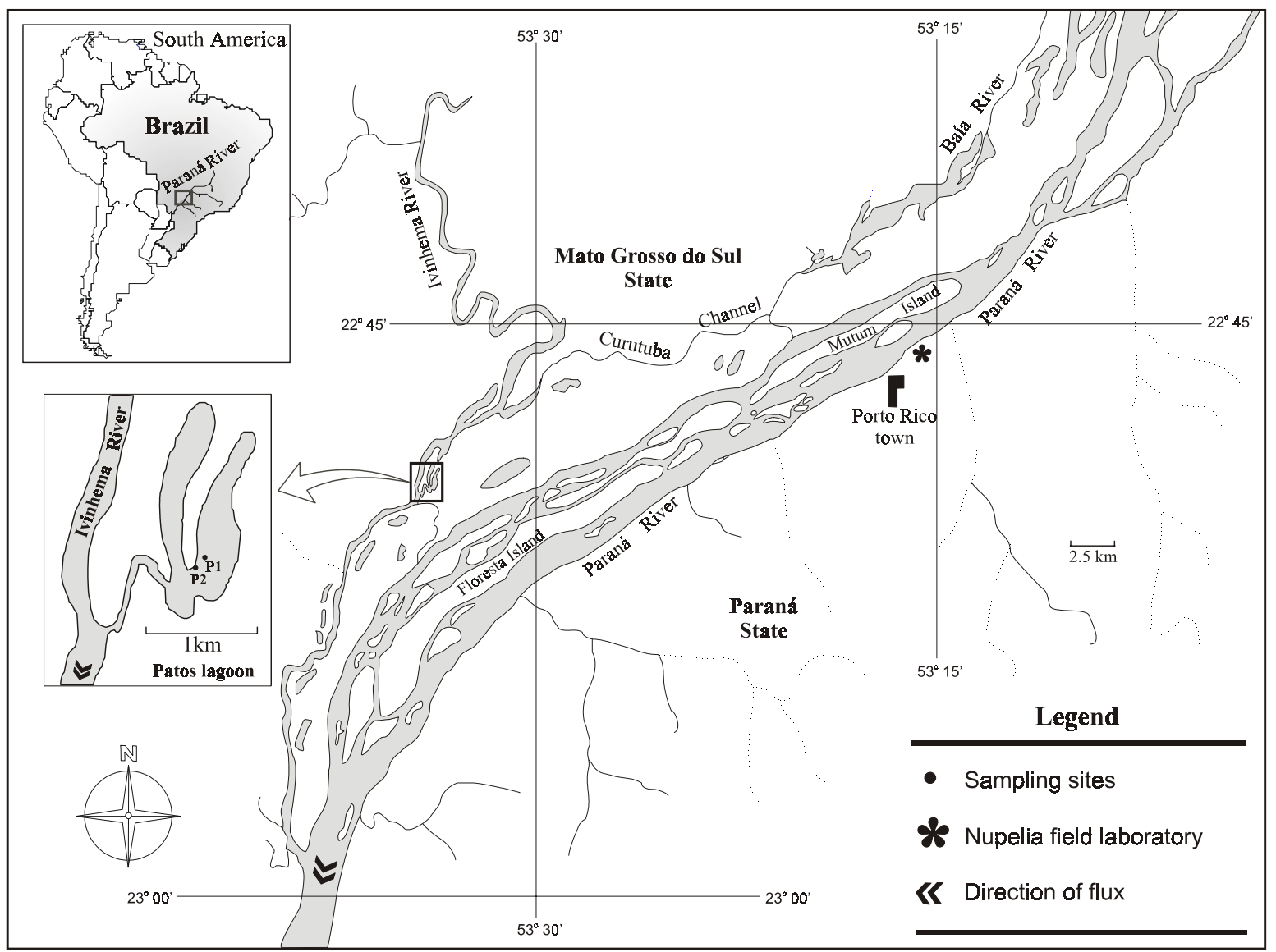

Figure 1 - Location of sampling sites in the pelagic region and in the littoral region of Patos lagoon 


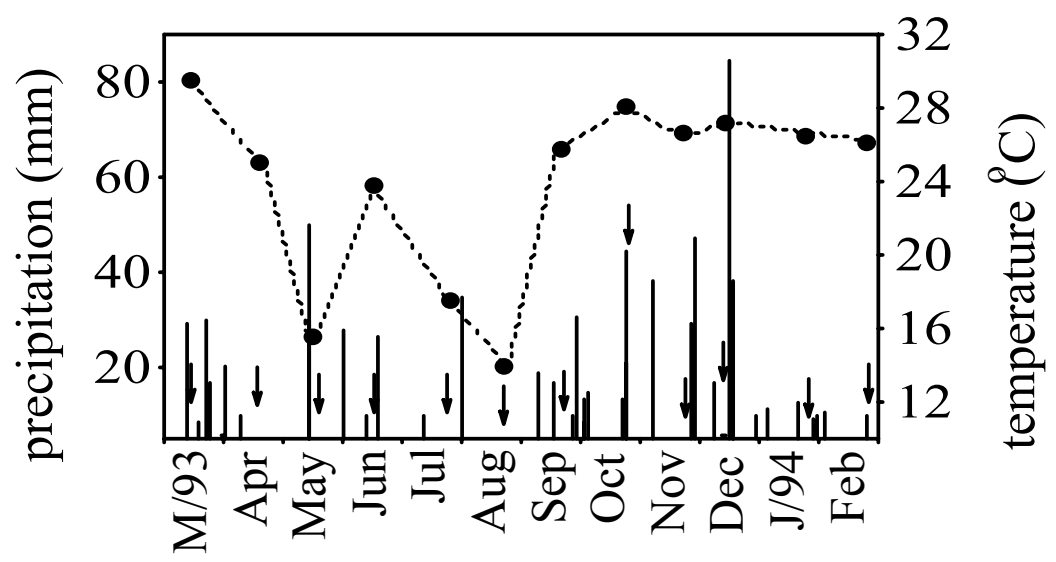

Figure 2 - Local daily precipitation (bars) and monthly air temperatures (stippled line) from March 1993 to February 1994. Arrows show sampling dates.

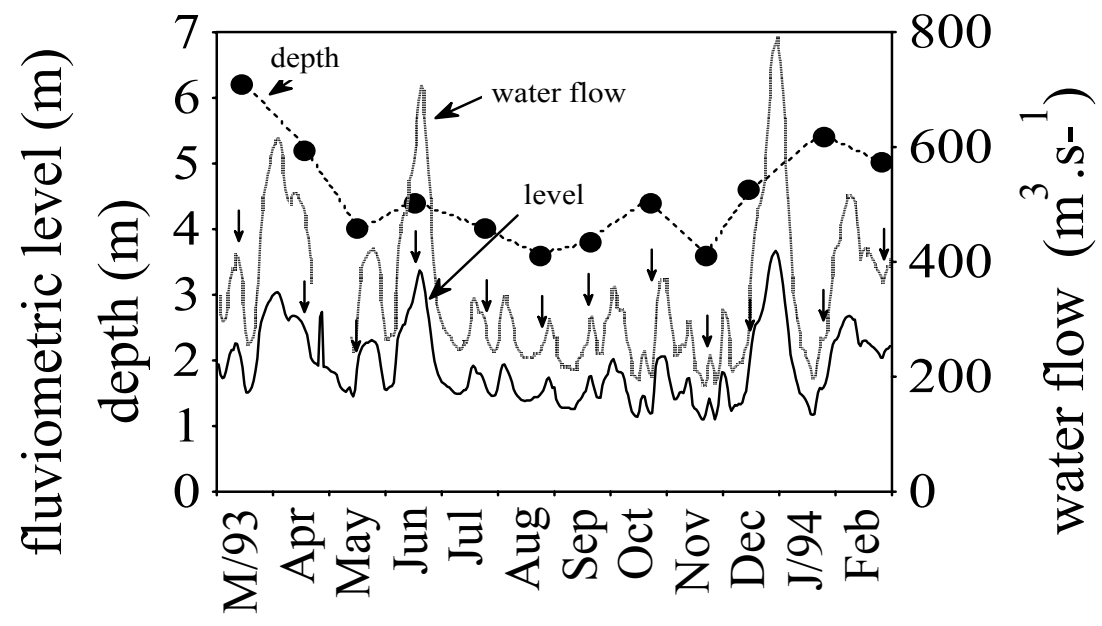

Figure 3 - Daily water levels and water flow measurements of the Ivinhema River and depth of lake from March 1993 to February 1994. Arrows indicate sampling dates.

In general, the depth of the Patos lagoon varied according to the water level of the Ivinhema River and fluctuated $2.5 \mathrm{~m}$ between the highest values registered in March and the lowest in August.

The most conspicuous vertical thermal gradients occurred in months with high water levels. Maximum difference of $3.5^{\circ} \mathrm{C}$ was observed in June in the limnetic region (Fig. 4, 5). This could be attributed to both high air temperatures in summer months and greater lagoon depth. Surface water layers heated up and the higher lagoon depth in this period made complete mixing difficult (Thomaz, 1991).
The euphotic zone spanned the entire water column in March, May, June and August in the limnetic region. In the very shallow littoral region, the euphotic zone spanned the entire water column in most months except November, December and February 1994. In the limnetic region, the euphotic zone was restricted to 29 and $33 \%$ of the water column during December and February.

In the limnetic region, total suspended material occurred in high concentration during low water periods and maximum values were observed in October and November (Fig. 6). The lowest values were observed in May, when the lake was over $4 \mathrm{~m}$ deep. In August and December, algae was 
probably the principal organic component of the suspended material when high levels of organic matter were observed (Fig. 13).

Water transparency had an inverse pattern, with a maximum value (2.85m) observed in March 1993.
During the low water period, transparency was low with the lowest values observed in October, November and December. In the last month, sampling was carried out before the elevation of the water level.
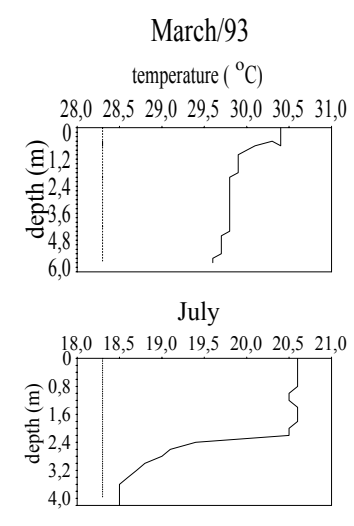

November

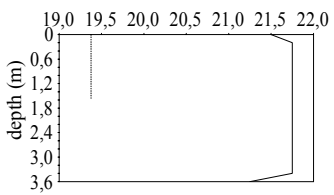

April

temperature $\left({ }^{\circ} \mathrm{C}\right)$

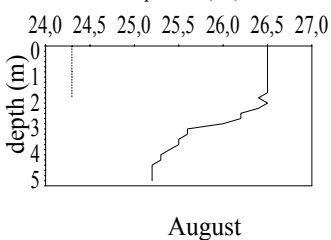

August

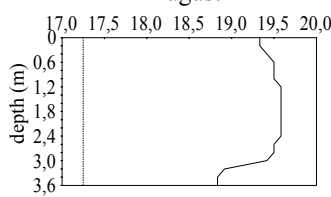

December

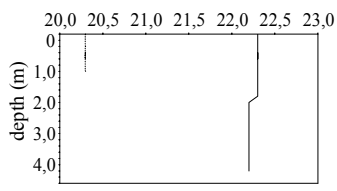

May

temperature $\left({ }^{\circ} \mathrm{C}\right)$
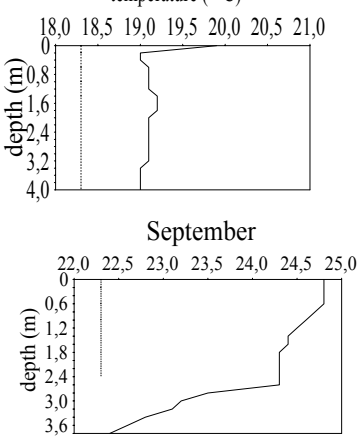

January $/ 94$

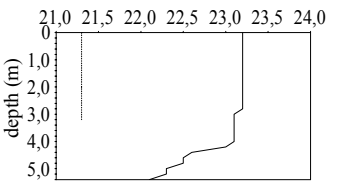

June

temperature $\left({ }^{\circ} \mathrm{C}\right)$

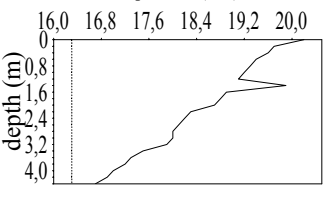

October

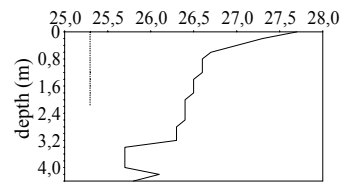

February

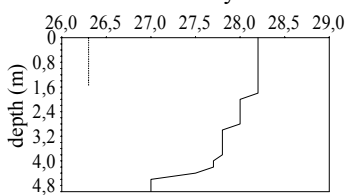

Figure 4 - Thermal profile (solid line) and euphotic zone (stippled line) in the limnetic region of Patos lagoon (P1) from March 1993 to February 1994.

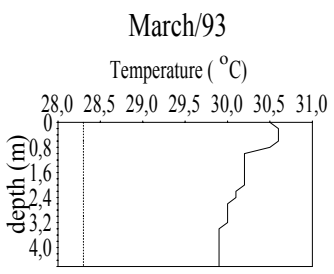

July

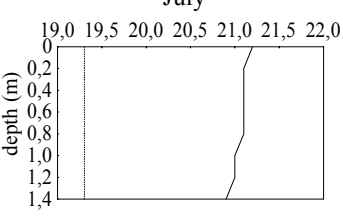

November

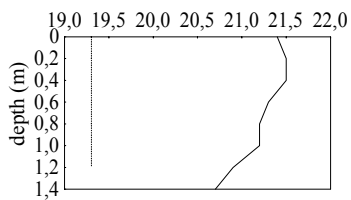

April

temperature $\left({ }^{\circ} \mathrm{C}\right)$

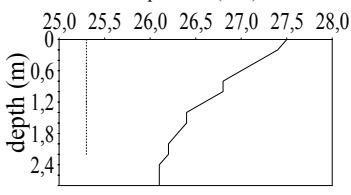

August

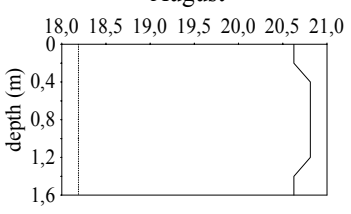

December

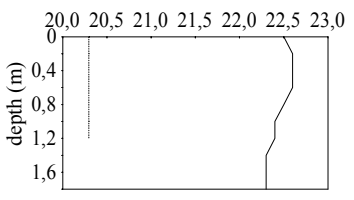

May

temperature $\left({ }^{\circ} \mathrm{C}\right)$

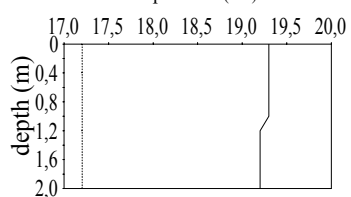

September

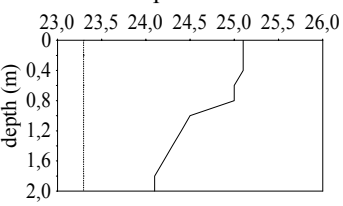

January/94

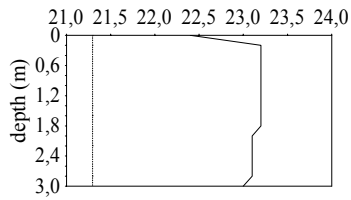

June

temperature( $\mathrm{OC})$

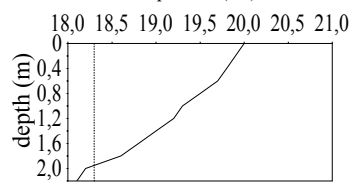

October
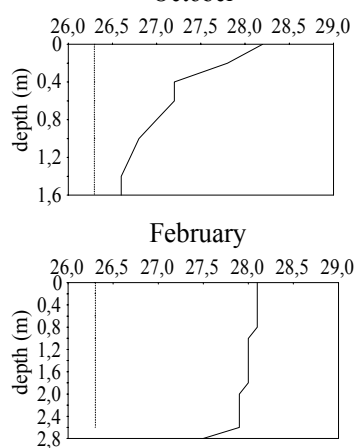

Figure 5 - Thermal profile (solid line) and euphotic zone (stippled line) in the littoral zone of Patos lagoon (P2) during the study period. 


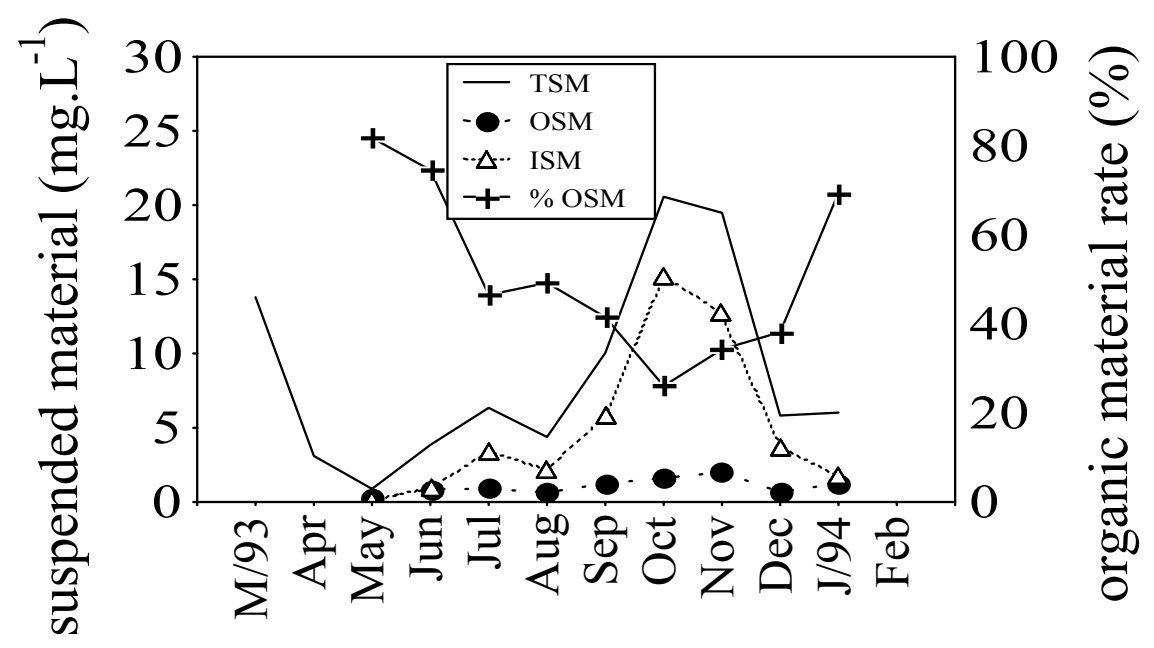

Figure 6 - Monthly concentrations of total, inorganic and organic suspended material and organic material rate in the limnetic region of Patos lagoon from March 1993 to February 1994.
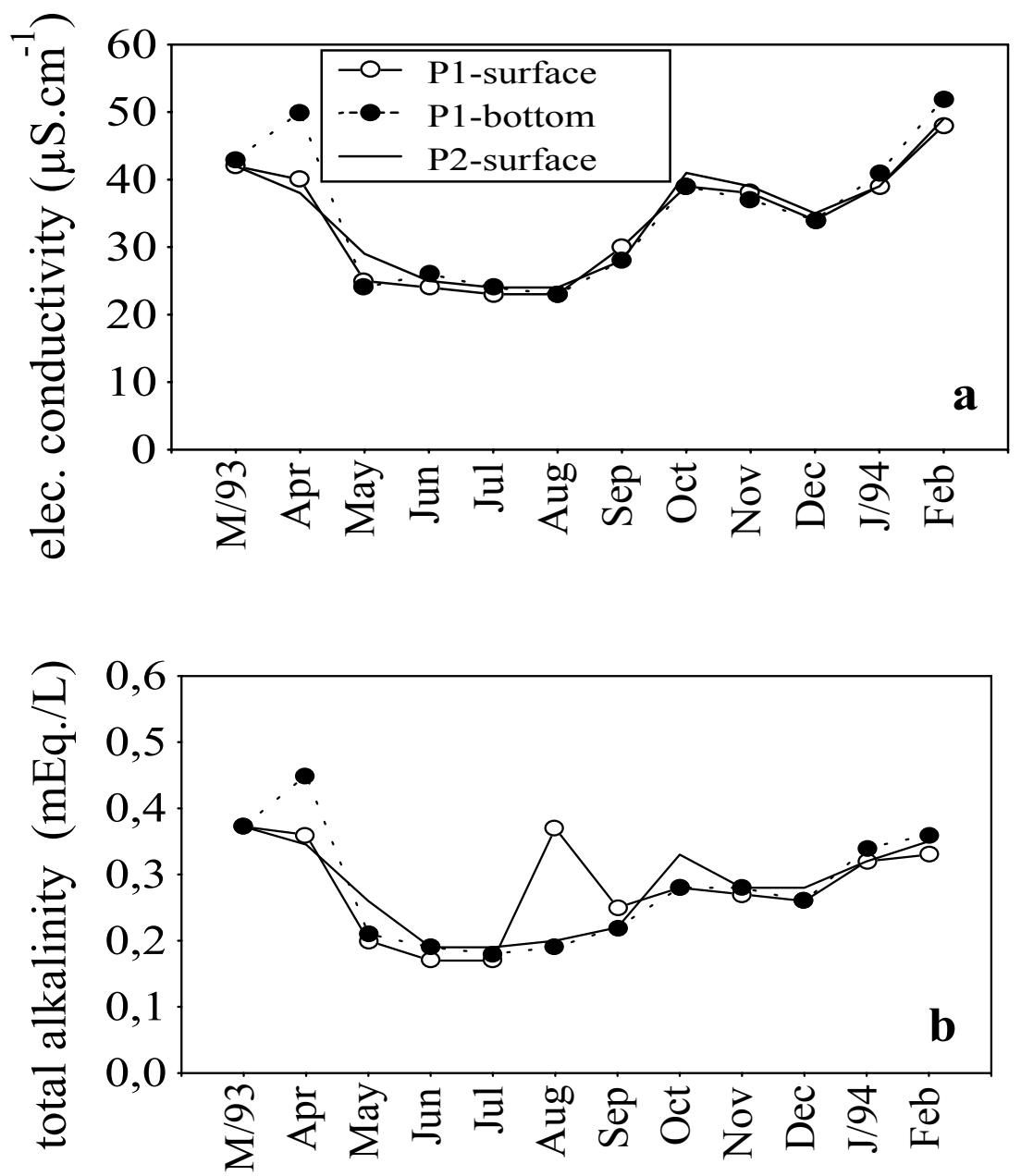

Figure 7 - Spatial and temporal variations of electrical conductivity (a) and alkalinity (b) in Patos lagoon from March 1993 to February 1994. 
In addition to this abiogenic turbidity, the high algae concentration at that time (Rodrigues, L. C., 1998) could have been responsible for the lower water transparency during the low water period. Thomaz et al. (1997) have reported an inverse relationship between water transparency and chlorophyll $a$ concentrations in the same lake, during the low water period.

Although the lowest water flow was observed in October and November, there was a decrease in the euphotic zone and an increase in the suspended material and nutrient concentrations. These conditions could be attributed to local rains that carried material from the floodplain to the lagoon, and to probably wind effect, which ressuspended sediments into the water column and increased nitrogen and phosphorus concentrations, as reported by Thomaz (1991) and Thomaz et al. (1992; 1997).

As emphasized by Thomaz (1991), each of the forcing functions had a maximum influence in floodplain lagoons in distinct phases of the hydrological cycle. Pluviometric precipitation and winds were probably the main factors occurring at end of the dry season, when the lagoon was shallow.

Electrical conductivity and total alkalinity showed the same temporal pattern, with the highest values during the high water periods (Figs. 7a, b). Bicarbonate values showed the same shape of total alkalinity, with values between $10.6 \mu \mathrm{g} . \mathrm{L}^{-1}$ (June) and $22.8 \mu \mathrm{g} . \mathrm{L}^{-1}$ (March) at the surface of the limnetic region.
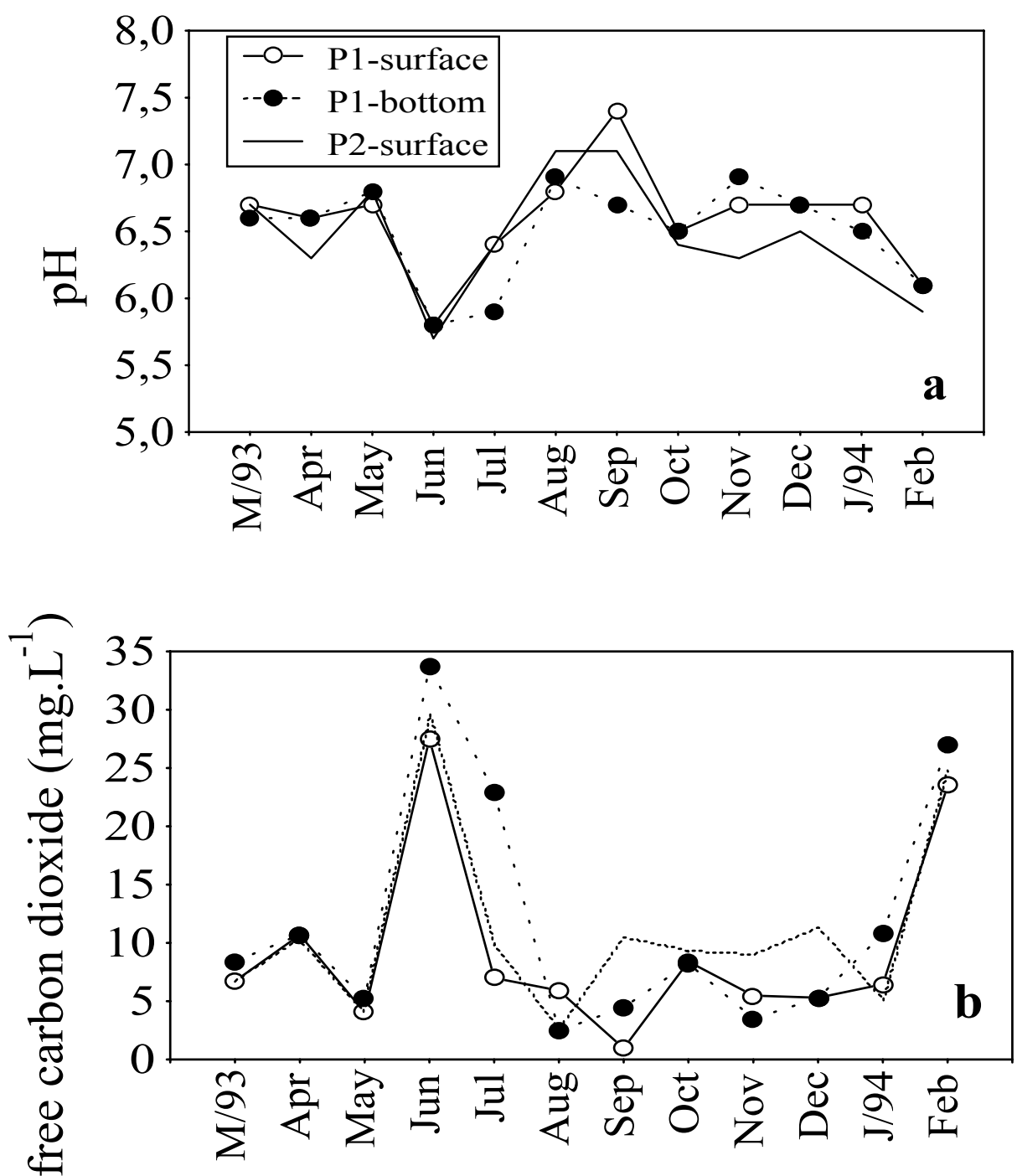

Figure 8 - Spatial and temporal values of pH (a) and carbon dioxide (b) in Patos lagoon from March 1993 to February 1994. 


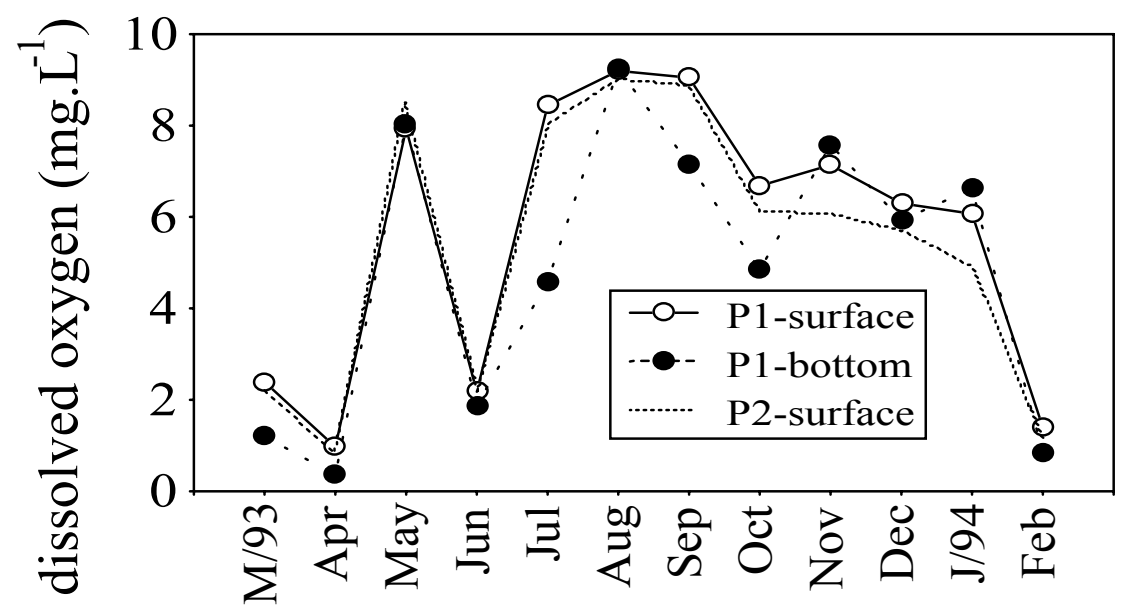

Figure 9 - Dissolved oxygen concentrations in Patos lagoon from March 1993 to February 1994.

$\mathrm{pH}$ values were slightly acidic in June when the lowest value (5.8) in the whole lake was observed (Fig. 8a). The highest $\mathrm{pH}$ values occurred during the low water period and could be attributed to the highest algal photosynthetic activity during this period (Rodrigues, L. C., 1998). The lowest pH values occurred when there was a reduction in oxygen concentrations and an increase in carbon dioxide, reflecting the active decomposition processes (Fig. 8b). The lowest values of carbon dioxide occurred during the low water period when there was high phytoplankton biomass. Dissolved oxygen varied from less than $1.0 \mathrm{mg} . \mathrm{L}^{-1}$ during the high water period to concentrations higher than $9.0 \mathrm{mg} . \mathrm{L}^{-1}$ during the low water period (Fig. 9).

These supersaturated waters could be attributed to high phytoplankton activity, given the high concentrations of chlorophyll registered at this time (Fig. 13).

During the high water period, Patos lagoon presented hypoxic conditions throughout the water column, probably due to the oxidation processes of decomposition of allocthonous organic matter and high temperatures.

In relation to nutrients, total nitrogen and total Kjeldahl nitrogen presented minimum values in March, which increased in subsequent months, probably due to the release of organic compounds from the flooded vegetation (Figs. 10a, b). The maximum values occurred from October to
December, when precipitation was also high. The rains probably promoted the ressuspension of nutrients from sediment. Another factor that could explain the peak in these nutrients during the dry season, mainly in August and September, is the occurrence of a heterocytous bluegreen algae bloom (Rodrigues, L. C., 1998).

Phosphorus increased after the inundation in March (Fig. 11), which could be attributed to the input of decomposing organic matter from the floodplain. The decomposition and oxidation of this material released organic compounds into the lake, increasing concentration of total particulate phosphate. The increase in phosphorus in floodplain lakes during floods was observed by Rai and Hill (1981); Thomaz (1991) and Train (1998). During low water periods, the high concentrations of these nutrients can be attributed to the rains carrying nutrients from the floodplain to the lagoon and to winds which, at that time, ressuspended sediment. During October and November, concentrations were in the range of $70,0 \mu \mathrm{g} . \mathrm{L}^{-1}$.

At the end of the rainy season, low concentrations of phosphates were registered, particularly reactive soluble phosphorus. Primary producers probably took up these nutrients, especially phytoplankton, which was abundant at this time (Rodrigues, L. C., 1998). 

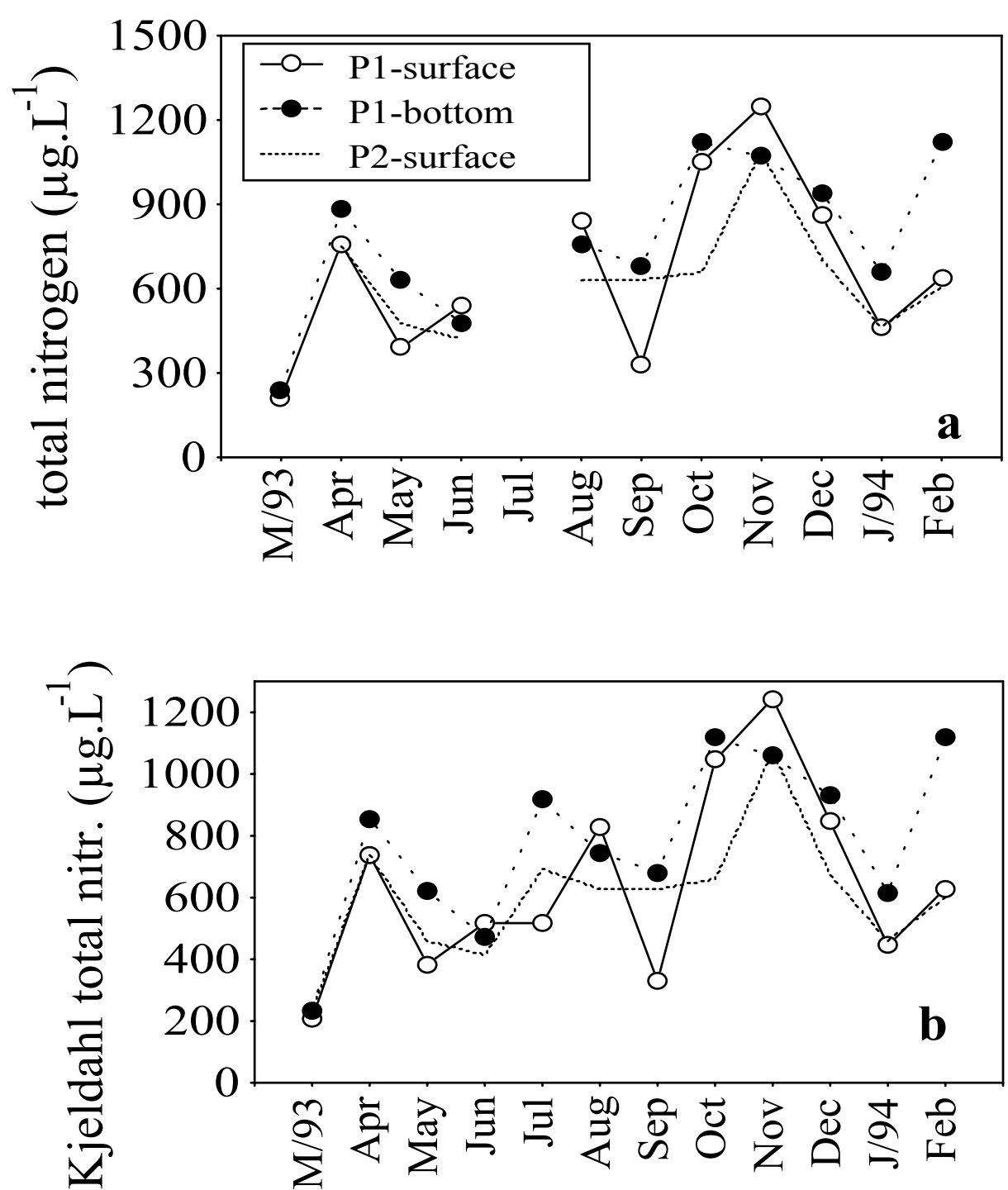

Figure 10 - Spatial and temporal concentrations of total nitrogen (a) and total Kjeldahl nitrogen (b) in Patos lagoon from March 1993 to February 1994.

The decrease in these nutrients at the end of the dry season was probably due to a dilution effect brought on by the inflow of the Ivinhema River into the lake (Thomaz et al., in prep.) and the incorporation by the algal biomass.

Phytoplankton biomass, estimated by the concentration of chlorophyll $a$ in Patos lagoon, presented a high inverse correlation with water level (Fig. 12). Highest concentrations occurred during the dry season, with a peak in December (Fig. 13). The lowest values were detected in June and February, when water level and flow of the
Ivinhema River were highest and the concentrations of nutrients decreased. High inverse correlation with water level, have been recorded in other floodplain lakes of the Upper Paraná River (Train, 1998) and Amazon basin (Huszar, 1994; Melo and Huszar, 2000).

The potamophase of this lake favours the turnover of the water column, which inhibits the occurrence of a permanent state of eutrophication. This condition could favour the development of planktonic bluegreens, as has been observed in developing studies in this region. 

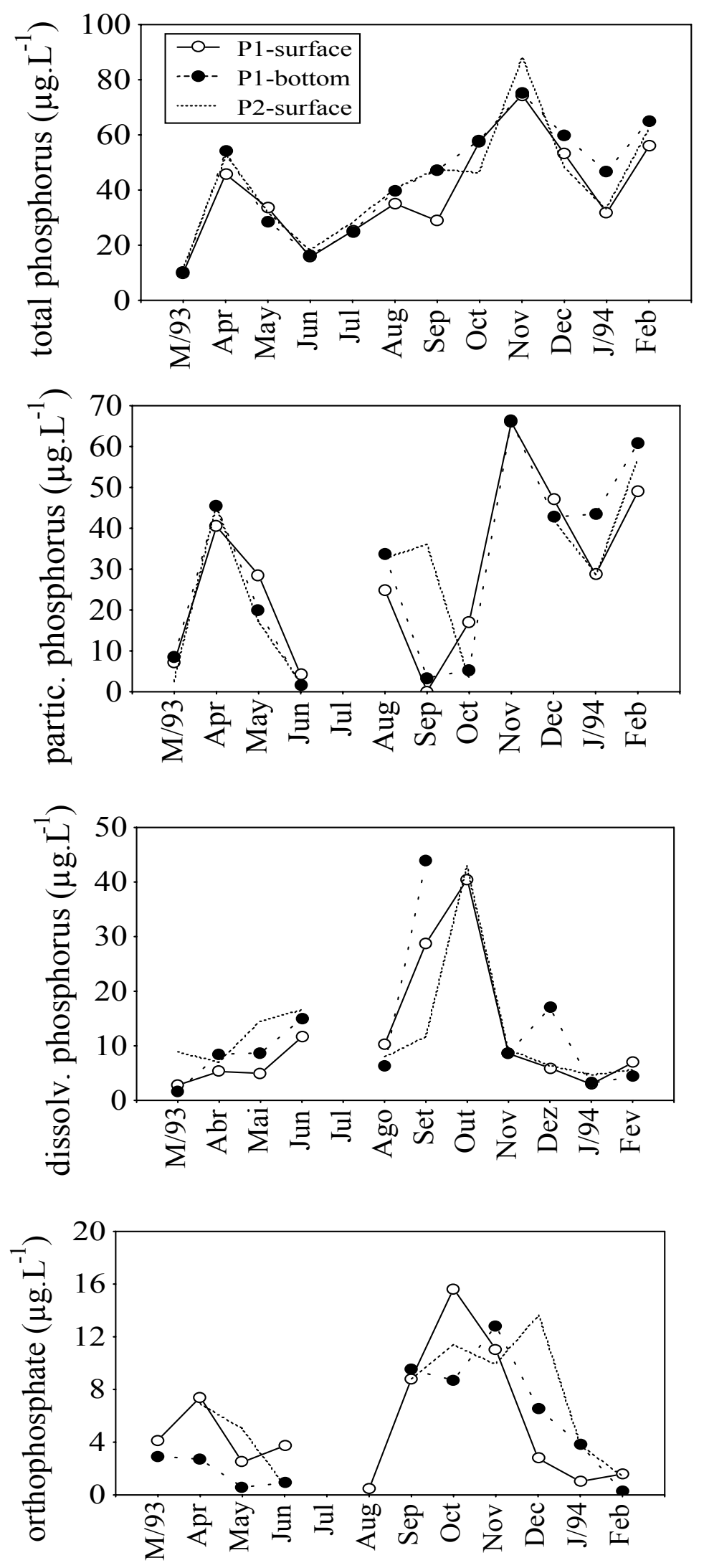

Figure 11 - Spatial and temporal concentrations of total, total particulated, dissolved phosphorus and orthophosphate in Patos lagoon from March 1993 to February 1994. 


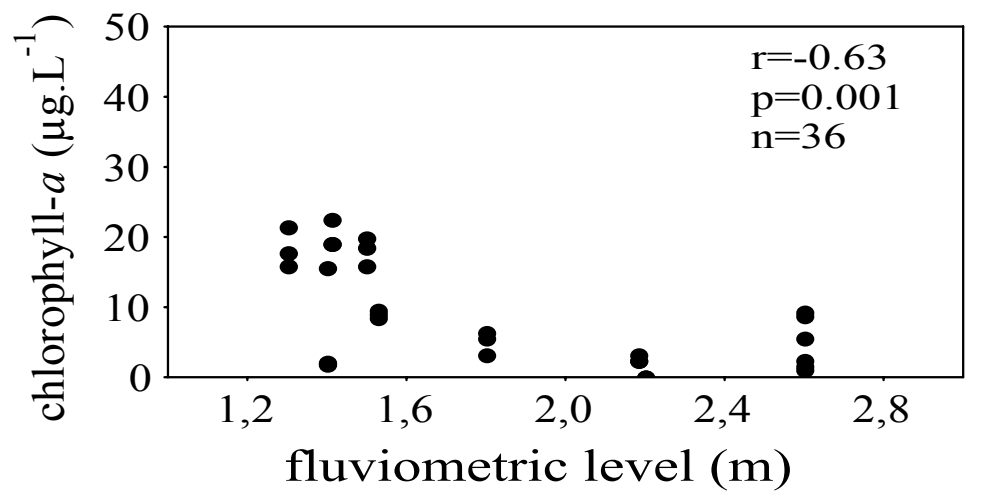

Figure 12 - Relationship between phytoplankton biomass in Patos lagoon and the Ivinhema River water levels from March 1993 to February 1994.

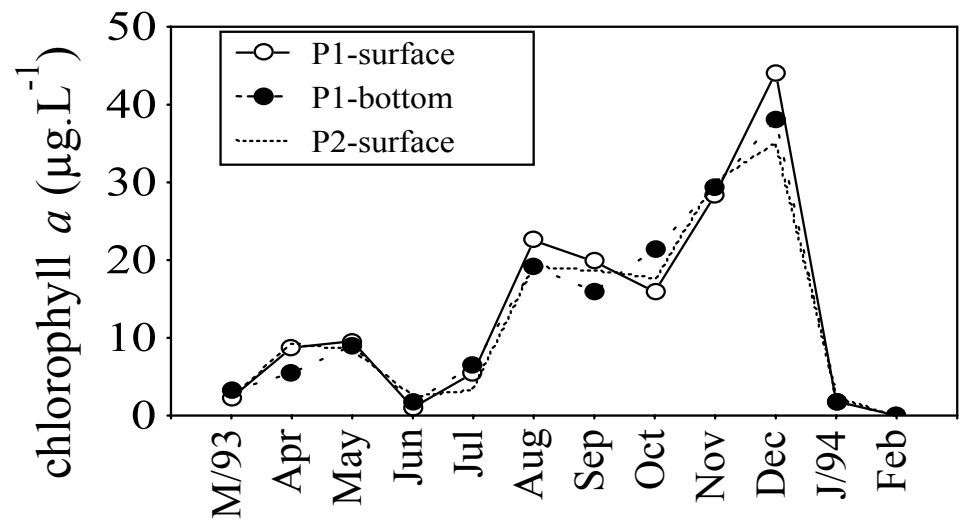

Figure 13 - Spatial and temporal phytoplankton biomass (chlorophyll a) fluctuation in Patos lagoon from March 1993 and February 1994.

A Principal Component Analysis produced two axes with eigenvalues greater than three. The first two axes represented $31 \%$ and $25 \%$, respectively, of inertia of the whole data set (Fig. 14).

Axis 1 was positively correlated to the highest values of carbon dioxide and negatively to low oxygen concentrations and low phytoplankton biomass, separating high and low water level months. The disturbance occurring in June probably resulted in the decomposition of the autochthonous biomass and explained the position of this sampling date with the high water levels. Although high water levels occurred in December, it was placed with the low water months, which could be explained by the beginning of the inundation period. During this period, limnological variables were influenced by the increased water level of the Ivinhema River.
Axis 2 also showed differences between the periods, according to the hydrological events. This was done mainly for the increase in transparency and decrease in electrical conductivity and total phosphorus in low rain and low water level periods. Apparently, limnological variables from September to December were influenced more by the precipitation regime. We also observed the same tendency for March and April 1993 and for January and February 1994. Limnological variables in March 1993 and January 1994 were influenced by the dilution effect of the flood, while in subsequent months these variables seemed to be influenced more by the decomposition of the flooded vegetation with consequent release of nutrients into the lagoon. 


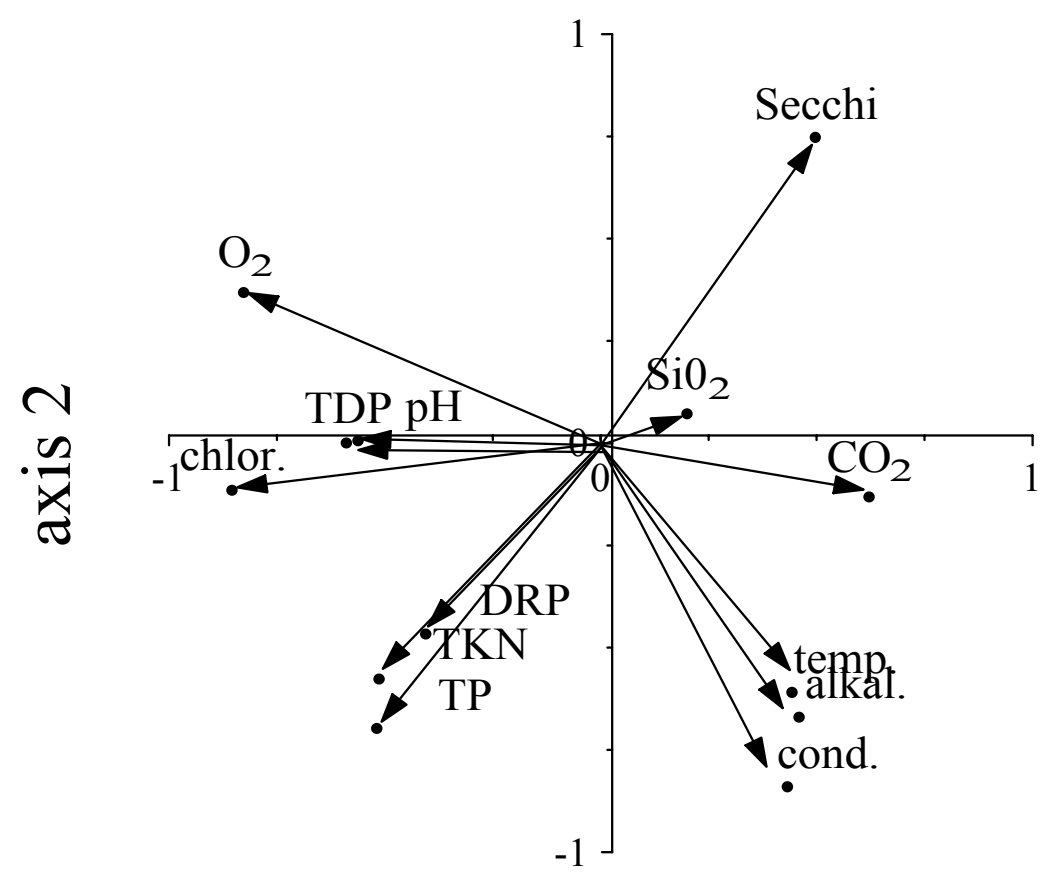

axis 1

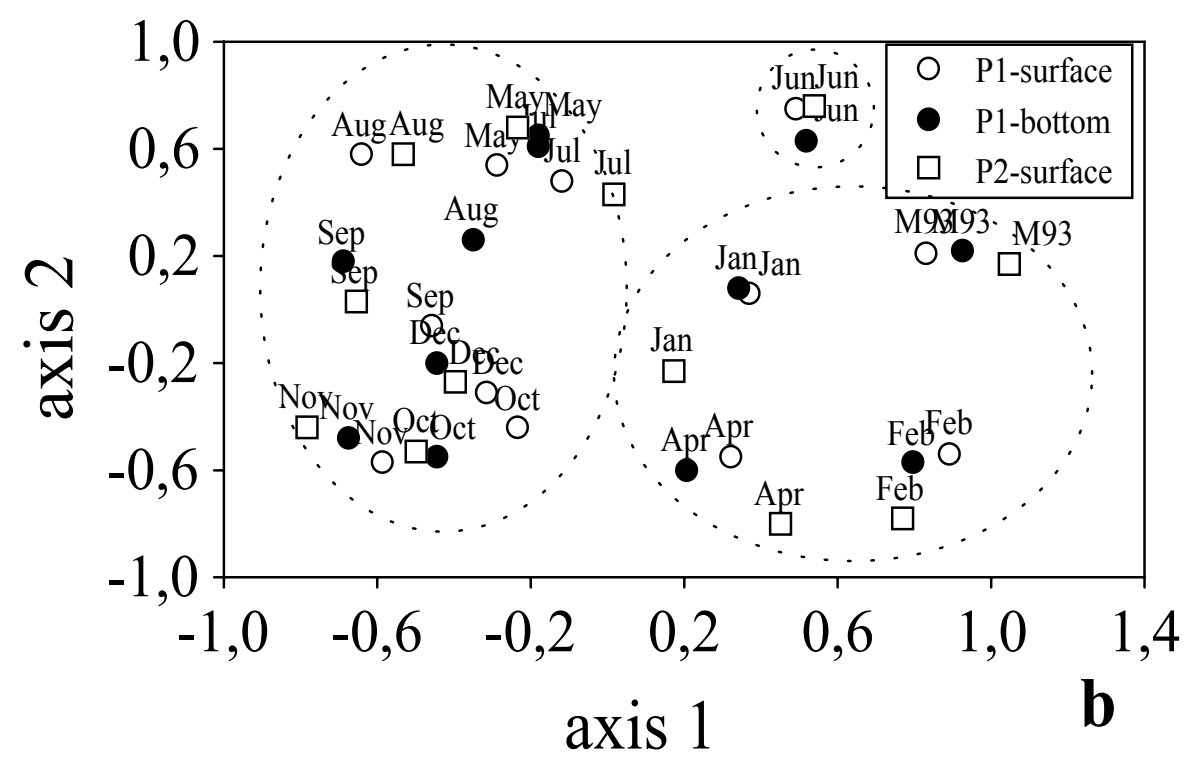

Figure 14 - Pearson's correlation among the original variables and scores (a). The sample scores are identified by sites-months (b). 


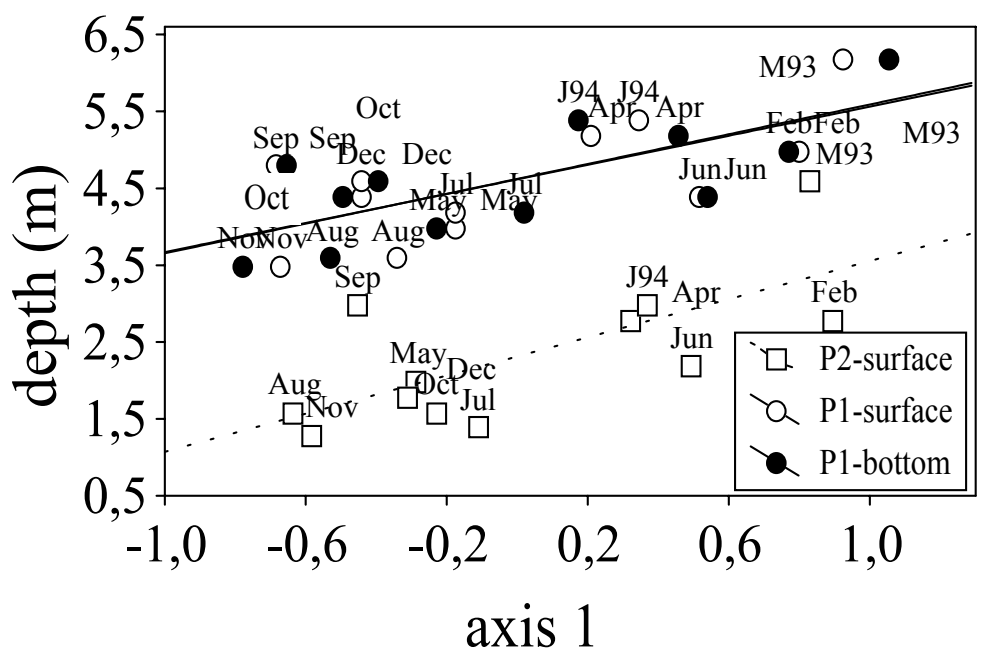

Figure 15 - Relationship between depth of lake and axis 1 of the PCA from March 1993 to February 1994.

A Pearson's correlation analysis was carried out between axis 1 of the PCA and depth values of the lake (Fig. 15). The same tendency was observed in both limnetic and littoral regions. A significant correlation was observed in the surface layer $(\mathrm{r}=$ $0.70, \mathrm{p}=0.01, \mathrm{n}=12)$ and in the deeper layer $(\mathrm{r}=$ $0.69, \mathrm{p}=0.01, \mathrm{n}=12$ ) of the pelagic region and in the littoral region of the lagoon $(\mathrm{r}=0.74, \mathrm{p}=0.006$, $\mathrm{n}=12$ ).

Therefore, this study showed the strong influence of the hydrological regime on the environments of the Upper Paraná River floodplain. Nutrients were diluted when there was an increase in connectivity due to the floods, followed by intense decomposition processes when the environments were interconnected. On the other hand, during the periods of low connectivity, physical and chemical processes were influenced more by local events such as precipitation.

\section{RESUMO}

Foram analisadas as flutuações temporais de algumas variáveis limnológicas, nas regiões limnética e litorânea de uma lagoa de inundação (lagoa dos Patos) da planície de inundação do alto rio Paraná $\left(22^{\circ} 43^{\prime} 12^{\prime}\right.$ 'S e $\left.53^{\circ} 17^{\prime} 37^{\prime} ' \mathrm{~W}\right)$ em relação a fatores climatológicos e hidrológicos. Temperatura da água, profundidade da zona eufótica, material em suspensão, condutividade elétrica, alcalinidade total, $\mathrm{pH}$, oxigênio dissolvido, dióxido de carbono, nitrogênio total, nitrogênio total Kjedahl, fósforo total, fósforo dissolvido, fósforo solúvel reativo e clorofila- $a$ foram medidas, mensalmente, de março de 1993 a fevereiro de 1994. Os resultados obtidos evidenciaram a importância do regime hidrológico sobre a dinâmica das variáveis limnológicas. Durante eventos de inundação, observou-se a diluição dos nutrientes da lagoa, especialmente das frações de fosfato, seguida de uma fertilização do ambiente por nutrientes da região marginal inundada. Nos períodos de baixa conectividade, eventos autóctones como ressuspensão do sedimento causada por chuva e ventos regem os eventos limnológicos na lagoa.

\section{ACKNOWLEDGEMENTS}

We thank INPA researcher Barbara A. Robertson for assistance with the English text. Thanks are also due to the staff of the Center for Research in Limnology, Ichthyology and Aquaculture (Nupélia, Universidade Estadual de Maringá) for technical and scientific support; to PADCT$\mathrm{CIAMB} / \mathrm{CNPq}$ for financial support and to CAPES for several scholarship grants. 


\section{REFERENCES}

Agostinho, A. A. and Zalewski, M. (1996), A planície alagável do alto rio Paraná: Importância $e$ preservação. Maringá : EDUEM.

Agostinho, A. A.; Vazzoler, A. E. A. M. and Thomaz, S. M. (1995), The High River Paraná Basin: Limnological and Ichthyological Aspects. In: Tundisi, J. G.; Bicudo, C. E. M. and Matsumura-Tundisi, T. (eds.). Limnology in Brazil. Rio de Janeiro : ABC/SBL. pp. 59-103.

Agostinho, A. A.; Thomaz, S. M.; Minte-Vera, C. V. and Winemiller, K. O. (2000), Biodiversity in the high Paraná River floodplain. In: Gopal, B.; Junk, W. J. and Davis, J. A. (eds.). Biodiversity in wetlands: assessment, function and conservation. The Netherlands, B. Publishers. pp. 89-118.

Cole, G. A. (1975), Textbook of limnology. Saint-Louis. C. V. Mosby.

Garcia, A. P. P.; Lansac-Tôha, F. A. and Bonecker, C. C. (1998), Species composition and abundance of rotifers in different enviroments of the floodplain of the upper Paraná River, Brazil. Rev. Bras. Zool., 15, 327-343.

Golterman, H. L.; Clymo, R. S. and Ohnstad, M. A. M. (1978), Methods for physical and chemical analysis of freshwater. Oxford : Blackwell Scientific Publication.

Higuti, J. (1998), Variação espaço-temporal das larvas de Chironomidae (Diptera) de duas lagoas e dois tributários da planície de inundação do alto Rio Paraná, Brasil. MSc Thesis, Universidade Estadual de Maringá, Maringá, Brasil.

Huszar, V. L. M. (1994), Fitoplâncton de um lago amazônico impactado por rejeito de bauxita (lago Batata, Pará, Brasil): Estrutura da comunidade, flutuações espaciais e temporais. $\mathrm{PhD}$ Thesis, Universidade Federal de São Carlos, São Carlos, Brasil.

Junk, W. J. (1980), Áreas inundáveis - um desafio para a limnologia. Acta Amazonica, 10, 775-795.

Junk, W. J.; Bayley, P. B. and Sparks, R. E. (1989), The flood pulse concept in river-floodplain systems. Can. Spec. Publ. Fish. Aquat. Sci., 106, 110-127.

Lansac-Tôha, F. A.; Lima, A. F.; Thomas, S. M. and Roberto, M. C. (1992), Zooplâncton de uma planície de inundação do rio Paraná. I. Análise qualitativa e estrutura da comunidade. Unimar, 14, 35-55.

Lansac-Tôha, F. A.; Bonecker, C. C.; Velho, L. F. M. and Lima, A. F. (1997), Comunidade zooplanctônica. In: Vazzoler, A. E. A. M.; Agostinho, A. A. and Hahn, N. S. (eds.). A planície de inundação do alto rio Paraná: aspectos físicos, biológicos $e$ socioeconômicos. Maringá : EDUEM. pp. 117-155.

Mackereth, F. Y. H.; Heron, J. and Talling, J. F. (1978), Water analysis: some revised methods for limnologists. Cumbria. Fresh. Biological Assoc., (Scientific Publication; 36).
Melo, S. and Huszar, V. M. L. (2000), Phytoplankton in an Amazonian Food-plain lake (lago Batata, Brasil): diel variation and species strategies. J. of Plank. Res., 22, 63-76.

Neiff, J. J. (1990), Ideas para la interpretação Ecologica del Paraná. Interciencia, 6, 424-441.

Pagioro, T. A.; Roberto, M. C.; Lansac-Tôha, F. A. and Veríssimo, S. (1994), Caracterização limnológica de uma lagoa (lagoa Figueira) da planície de inundação do alto rio Paraná. Unimar, 16, 203-215.

Pagioro, T. A.; Roberto, M. C. and Lansac-Tôha, F. A. (1997), Comparative limnological analysis of two lagoons on the floodplain of the upper Paraná River, Brazil. Internat. J. of Ecol. and Environ. Sc., 23, 229-239.

Pagioro, T. A. and Thomaz, S. M. (1999), Decomposition of Eichhornia azurea from limnologically different environments of the Upper Parana River floodplain. Hydrobiol., 411, 45-51.

Rai, H. and Hill, G. (1981), Physical and chemical studies of lago Tupé; a Central Amazonian black water "Ria Lake”. Int. Revue Ges Hydrobiol., 66, 1-49.

Rodrigues, L. (1998), Sucessão do perifiton na planicie de inundação do Alto Rio Paraná: interação entre nível hidrológico e regime hidrodinâmico. $\mathrm{PhD}$ Thesis, Universidade Estadual de Maringá, Maringá, Brasil.

Rodrigues, L. C. (1998), Estrutura da comunidade fitoplanctônica de uma lagoa marginal do rio Ivinhema (lagoa dos Patos, planície de inundação do alto Rio Paraná) em diferentes períodos do ciclo hidrológico. MSc Thesis, Universidade Estadual de Maringá, Maringá, Brasil.

Serafim, M. (1997), Heterogeneidade espacial e temporal da comunidade zooplanctônica do sistema rio Ivinhema-lagoa dos Patos, Planície de Inundação do Alto Rio Paraná (MS). MSc Thesis, Universidade Estadual de Maringá, Maringá, Brasil.

Souza Filho, E. E. and Stevaux, J. C. (1997), Geologia e geomorfologia do complexo rio Baía, Corutuba, Ivinhema. In: Vazzoler, A. E. A. M.; Agostinho, A. A. and Hahn, N. S. (eds.). A planície de inundação do alto rio Paraná: aspectos físicos, biológicos $e$ socioeconômicos. Maringá : EDUEM. pp. 3-43.

Statistic, (1996), Evanston: Systat Inc.

Takeda, A. M.; Shimizu, G.Y. and Higuti, J. (1997), Variações espaço-temporais da comunidade zoobêntica. In: Vazzoler, A. E. A. M.; Agostinho, A. A. and Hahn, N. S. (eds.). A planície de inundação do alto rio Paraná: aspectos físicos, biológicos $e$ socioeconômicos. Maringá : EDUEM. pp. 157-177.

Thomaz, S. M. (1991), Influência do regime hidrológico (pulsos) sobre algumas variáveis limnológicas de diferentes ambientes aquáticos da planície de inundação do alto rio Paraná, MS., Brasil. MSc Thesis, Universidade Federal de São Carlos, São Carlos, Brasil. 
Thomaz, S. M.; Roberto, M. C.; Lanzac-Tôha, F. A.; Lima, A. F. and Esteves, F. A. (1992), Características limnológicas de uma estação de amostragem do alto rio Paraná e outra do baixo rio Ivinhema (PR, MS, Brasil). Acta limnol., 4, 32-51.

Thomaz, S. M.; Roberto, M. C. and Bini, L. M. (1997), Fatores limnológicos abióticos e clorofila- $a$ : caracterização dos habitats e influência do pulso de inundação. In: Vazzoler, A. E. A. M.; Agostinho, A. A. and Hahn, N. S. (eds.). A planície de inundação do alto rio Paraná: aspectos físicos, biológicos $e$ socioeconômicos. Maringá : EDUEM. pp. 371-394.

Train, S. (1998), Flutuações temporais da comunidade fitoplanctônica do subsistema rio Baía - Lagoa do Guaraná, Planície de inundação do alto rio Paraná (Bataiporã, MS). $\mathrm{PhD}$ Thesis, EESC/USP, São Carlos, Brasil.
Train, S. and Rodrigues, L. C. (1997), Distribuição espaço-temporal da comunidade fitoplanctônica. In: Vazzoler, A. E. A. M.; Agostinho, A. A. and Hahn, N. S. (eds.). A planície de inundação do alto rio Paraná: aspectos físicos, biológicos e socioeconômicos. Maringá : EDUEM. pp. 103-13.

Wetzel, R. G. and Likens, G. E. (1991), Limnological analysis. 2. ed. New York : Spring-Verlag.

Zalocar de Domitrovic, Y.; Asselborn, V. M. and Casco, S. L. (1998), Variaciones espaciales y temporales del fitoplancton en un lago subtropical de argentina. Rev. Brasil. Biol., 3, 359-382.

Received: February 15, 2001; Revised: July 07, 2001; Accepted: February 04, 2002. 


\section{PÁGINA}

\section{EM}

BRANCO 